Social Networks and Health Governance

${ }^{1}$ Programa de PósGraduação em Sociologia, Departamento de Sociologia, Centro de Filosofia e Ciências Humanas, Núcleo de Pesquisas sobre Redes Sociais e Poder. Universidade Federal de Pernambuco. Av. Acadêmico Hélio Ramos $\mathrm{s} / \mathrm{n} / 12^{\circ}$, Cidade Universitária. 50740530 Recife PE Brasil. brenofontes@gmail.com
Abstract This paper addresses the health challenges of contemporary societies, where stakeholders with diverse, and sometimes antagonistic interests, are faced with the establishment of a public agenda for the health care of the population. In this field, the modern welfare state plays an important role, not only as an implementing agent of the public agenda but also as a guarantor in the provision of services. In this essay, we will explore the concept of governance, which seeks to analyze the new governance practices in late modernity, incorporating the complicated relationship among stakeholders, in a scheme where ingredients such as popular participation and social control of public affairs are put to the fore. The theme of networks is introduced as an instrument for understanding the phenomenon of governance. The concept of health governance is constructed to explain the phenomena of new organizational schemes of public management, especially from the fact that new actors enter the stage. It is no longer possible to have a close picture of reality by using traditional organizational analysis models. It is essential to incorporate other theoretical-methodological instruments, and we believe that the analysis of social networks is an essential tool for understanding this complex reality.

Key words Health, Social networks, Governance 


\section{Social networks and health governance}

The art of governing - which raises the critical question of what good governance means - has been a significant concern among social thinkers, and in the West, this can be found from the Greeks of classical antiquity. Lato sensu, governing means to have control over something. Stricto sensu, now referring to the meaning that we will use henceforth relates to the way people organize, distribute and control resources, almost always in association with others. All forms refer to societal fields, even the most restricted ones, those that associate with the government of oneself, inscribed in the field of morality. This concept goes through successive modifications of meaning, preserving some crucial points, and incorporating others, always adapting to the vicissitudes of time. As we shall see later, a derived expression, governance, embodies the classical heritage, but also rejects other interpretations of modernity, bringing to light the vital facets of sociability processes of our late modernity.

In this essay, we will work with the concept of governance, which seeks to reflect on the new governance practices in late modernity, incorporating the complicated relationship between actors, in a scheme where ingredients such as popular participation and social control of public affairs are put to the fore.

\section{Health networs and systems: new fields and practices in the (de/re)construction of the welfare state}

The European healthcare system - a source of inspiration for most welfare state models replicated worldwide - was organized from two basic models, both of which were based on the distribution of care to the national community, seeking universality in the provision of service: (a) The so-called Bismarkian originates in Germany in the late nineteenth century and assumes that workers must have social and health care. Organized in pension funds, with contributions from workers and their employees, access is provided from services provided by the federated states (Bundesland), which organize the insurance funds, remunerating service providers (medical professionals, hospitals, clinics, among others). Recently, this model also adds another, of a private nature, with health insurance provid- ed by the market, which covers about $10 \%$ of the population $^{1}$. For those with no income (the unemployed, the young students, people with disability) or who receive insufficient income, the state guarantees the assistance; (b) the English Beveridgnian model, whose main characteristic is public financing, from the tax fund of health services. Organized from the NHS (National Health System), the system's distinctive feature is universality, built on the principle of tax solidarity: all contribute to taxes, which are allocated according to each individual need. It has strong state regulation and is also characterized by red tape rigidity. It is centralized from the various ethnic communities that make up the United Kingdom (Northern Ireland, England, Scotland, and Wales) and system users have little choice for service providers - mostly, initially, public service members, GPs (General Practitioners) and specialized medical care. Recently, in the 1990s, it undergoes reformulations, aiming at the greater participation of users and freedom in the choice of services ${ }^{2}$.

During much of the twentieth century, these systems were organized according to the classical principles of bureaucracy: strongly centralized, vertical organization and low communication with the public. Once decided in the public sphere, the health policy was the object of instrumentalization of the providing Institutions, within the rationale of bureaucratic reason. Little attention was paid to the whole medical system, now using the concept formulated by Jansen ${ }^{3}$, "the set of existing healing practices", relying almost exclusively on the biomedical model. Thus, there was little communication with the healing practices found in society, in the so-called lay systems. Also, as a consequence, the relationships between health professionals and those seeking care were characteristically vertical. This is happening not only in the narrower field of service provision but also throughout the rigid, vertical system, with clear chains of command and negligible attention to external questions.

More recent studies in the organizational and political field show that reality is much more complicated. As Merton ${ }^{4}$ points out, bureaucracies fail, they evidence dysfunctions, and their underpinning actors can often behave in a non-rational way. In the political field, authors such as Offe $^{5}$ and Habermas ${ }^{6}$ clearly show that the fields of communication between civil 
society and the state, mediated by political society, do not operate as quietly as the old theories tried to show. There are severe problems of legitimacy - Offe emphasizes the fiscal crisis and the consequent inability of the State to process the growing demand for services in the design of the welfare state; Habermas stresses the antinomy between instrumental reason - which self-manifests in the spheres of sociability instrumented by money and power - and substantive reason, with predominant expression in the world of life. Money and power subjugate civil society, transforming it into hostages of interests that do not translate into those rooted in the daily lives of people. This impossibility frontally attacks the models of sociability inscribed in modernity, that is, the centrality and apparent peaceful coexistence between rationality oriented by ends and that oriented by values.

More recent developments suggest profound changes in the welfare state, resulting from complex socioeconomic processes known as globalization or mundialization, which disorganize the foundations of the national state, with profound rearrangements in its organizational structure, and in its structure of legitimation. In addition to the profound fiscal crisis that national states have experienced since the 1970s, with a diminishing capacity to process the legitimating inputs (mostly stemming from growing demands for social benefits), global society imposes new standards of capitalist accumulation, with disruptive processes in the regulatory capacity of national states (a process known as deterritorialization and reterritorialization).

From the 1970s onwards, a significant series of changes took place on the planet, strongly impacting the sociability structures present since the beginning of the century: the Fordist model of production, the welfare state, and political organization strongly anchored in political parties and unions. With the profound changes brought about by the computer revolution, new practices of productive organization and state management were introduced, a result of what authors like Manuel Castells ${ }^{7}$ call the information society: a complicated process of restructuring capitalism, with economic systems increasingly interconnected and an extensive restructuring of national states, a direct result of the processes of deterritorialization triggered by information flows $^{8,9}$.
These changes cause a deep crisis of legitimation that considerably affects the organization of the political system and public management. In the case of the national states built from the Napoleonic model of management - centralization and traditional bureaucratic organization - a movement for decentralization (Spain, Italy, France, and Portugal have reorganized their public management models in the late 1970s) emerges, giving more power to local and regional political-administrative units - which some authors call the shift of the sphere of legitimacy, reducing or dispersing popular pressures ${ }^{10,11}$. A decentralization movement is also observed in Latin America, but it results from the profound crisis of legitimacy that authoritarian regimes have experienced since the mid-1980s $\mathrm{s}^{12-14}$.

The legitimacy crisis of traditional instruments of political organization, parties and unions, and the emergence of new social movements, political practices that seek the construction of new identities, must also be considered as an essential variable. Furthermore, an increasing pressure of the population for mechanisms of popular participation in public management occurs. The political decentralization movements are accompanied by new managing ways, with the entry of stakeholders in the formulation and control of public policies.

Thus, as the main constituent ingredient of the concept of governance, the entry of new political actors, with new "patterns of articulation and cooperation between social and political stakeholders"15, introducing new management models where technical rationality, central variable in previous analyses, is now mitigated, and actions and guidelines not properly bureaucratic are also playing important roles.

Also in this direction is the role of the new stakeholders, and many analysts understood that this new way of governing would be much more efficient and inclusive ${ }^{16}$ since, with the cooperation of civil society, voices unheard before would be considered now. We witness the emergence of ideas such as collaborative governance ${ }^{17}$, or greater autonomy for local governments ${ }^{18}$, in short, essential changes in the governance structure of public affairs.

However, analysts become more skeptical as governance processes consolidate. Many variables are strategic to the success of the new model and cannot be controlled, such as the level of 
organization of civil society, and the adaptive capacity of the bureaucratic apparatus to withstand the new changes.

There is also another critical point to be considered: management models have become much more complicated, requiring analytical procedures that take account of this diversity of stakeholders and possible arrangements between them. The old inter-organizational models of analysis are no longer efficient.

We assume that systems operating in interrelated fashion and with relative stability - even assuming, to the limit, that Luhman's autopoiesis formula ${ }^{19}$ considers in any way more dynamic structures than the more traditional ones - are put aside if we put into question the aspects of nonlinear changes, or even of the flexibility of the possible arrangements between the actors underlying the system ${ }^{20}$, considering as limit "the measure of the fractions of the apexes or connections that can be removed before the complete dissolution of the structure"21. Complex systems require particular approaches to the examination of their dynamics, and network analysts agree that the state of the art of research is still in its infancy ${ }^{22}$.

Recently, analysts have focused on the theoretical-methodological possibilities of the analysis of social networks for the study of public policies. Defined from the complex articulation between stakeholders, the phenomenon of social networks has a relational characteristic, different from that seen in traditional analyses, where the characteristics of stakeholders' attributes are essential ingredients to their understanding. Moreover, the networks are known to be flexible, and the study of their dynamics assumes characteristics close to complex systems models. The unpredictability or non-linearity of their behavior poses substantial challenges to the researcher.

As a complex system, health management is facilitated from the perspective of analyzing social networks. The health system is understood here in a broader way, including social practices geared to care and healing, including those not officially set ${ }^{23}$. Thus, we have the lay knowledge, the established and accredited practices, all understood as medical practices. It is also necessary to demarcate the idea of health networks (involving a broad spectrum of care and healing practices) and health networks governance, incorporating actors involved in established care and healing systems. The term of governance as employed here refers directly to the capacity of public stakeholders to promote the participation of their civil society counterparts. Thus, we have the idea of strengthening or improving accountability between clients and providers ${ }^{24}$, with mechanisms of control and participation in the management of health services, which has sometimes been termed network administration, suggesting a more flexible and collaborative actor interaction mode ${ }^{25}$, a complex network governance model ${ }^{26}$ :

Public management is the governance of complex networks, made up of different stakeholders located at national, state or local levels, political and social groups, interest and pressure groups, social movements and public and private organizations. Public governance is the influence of societal processes in a network of multi-stakeholder governance. These players have diverse, and often conflicting interests. The government is not a dominant actor who can impose its wishes unilaterally. Authoritative centralization hierarchical structures and top-down actions often do not work in a network.

Thus, when we look at governance models in health, the methodology of networks is beneficial to us, since it allows us to grasp more accurately the complex relationships among stakeholders. However, even if we disregard broader fields of health networks, such as epidemiology ${ }^{27,28}$, the analysis of network governance understood in the narrower sense of new public management practices cannot be done unless we set boundaries. In an analogy to Luhmann ${ }^{19}$, the social world as a system requires us to separate it from the environment, on the one hand, and also to discover in this broad social universe subsystems integrated with each other but autonomous and therefore analyzable in isolation. This is what Fuhse ${ }^{29}$ proposes in general, organizing the connections and boundaries between complex social systems consisting of autonomous reticular fields, but integrated with each other. Likewise, when thinking about health network governance, an analytical effort must be made to divide the contour of this broad, wide reticular field into subsystems, which allows, in a reticular matrix, to highlight parts of the more extensive system with similar characteristics.

Thus, Bruns ${ }^{30}$ proposes levels of analysis, namely, the primary, secondary and tertiary, classified according to patterns of sociability among the actors, and levels of allocated resources. 
Roughly, the primary level refers to the sociabilities found in strong ties and allows allocations of resources based on the social support; the secondary level, with patterns of sociability anchored in strong ties, but with identity structures anchored in the community: such sociabilities are found in the religious and neighborhood associations. Finally, the tertiary level, with sociabilities built entirely from weak links, those established between service providers (public agents providing health services, for example), and users. Sociabilities oriented to heavily regulated and formally established standards (procedures and protocols, legislation, for example). A similar classification was made from the viewpoint of organizational regulation and sociability practices: socio-technical network, social-institutional network, and human-social network ${ }^{31}$.

\section{The challenges of health governance}

In the new governance model, these reticular fields communicate, and often the examination of a specific policy requires us to articulate practices with stakeholders located at different interaction levels. However, even knowing this interrelationship, it is impossible to construct analytical models considering the whole reticular web. It always becomes necessary for the analysis to highlight some actors in a specific interactive field. We submit some examples below of research agendas that instrumentalize the methodology of networks in fields of health practices inscribed in the conceptual realm of network governance.

1. An interesting case is the policy to combat HIV/AIDS in Brazil. Brazil has been recognized worldwide for the excellence of its program in the HIV/AIDS epidemic, and this success is due to a successful articulation between the reticular fields located at more formally structured levels of sociability, such as government agencies, and those more inscribed in the field of civil society, as is the case of the social movements and non-governmental organizations. In fact, HIV/ AIDS prevention and treatment policies operate in three distinct fields, all of which have a significant presence of NGOs and Social Movements, often articulated with government agencies: (a) participation in various Councils and Commissions organized by the State (at the federal, state and municipal levels); (b) in the independent action, articulated in a network, aiming to real- ize the social control of public actions; (c) in the production of public assistance, care and prevention campaigns, with public or private funding ${ }^{32}$.

2. Another very illustrative example concerns the sociabilities inscribed in what I called a social and institutional network, one that aims to stimulate solidarity and favor articulated actions between agencies and stakeholders involved in the formation of a public sphere at the local level ${ }^{33}$. In empirical research on the Family Health Strategy in the city of Recife, I could identify the impact of local arrangements of sociabilities - associative practices - on the governance model adopted by the municipality. The family health program has proved to be an important tool in health promotion and prevention; it consists basically of the premise that health is a matter to be handled in integration with the team of professionals (physicians, nurses and community health workers (ACS) basically) and the community. Visits to families, knowledge of the local reality, and cooperation with residents' associations, NGOs and public institutions (School, police station, Specialized Welfare Reference Centers) are essential ingredients in the Family Health Care model. As we pointed out earlier, the analysis of the insertion of ACS in the local associative web is an important methodological tool insofar as we allow the different designs or configurations of the networks to influence the level of efficiency of public policies. What is posed as a question is, on the one hand, the stance of individuals in the local associative networks, the actors' capacity of articulation and their insertion in the community; on the other hand, what is more important, we analyze the capacity of introducing the PSF in the network of sociability of their operational territory $y^{34}$.

Associative networks are not uniformely distributed throughout the urban fabric; some neighborhoods have a much greater presence of residents' associations and NGOs, while in some other, they are almost nonexistent; and in other locations, such as the Coque neighborhood, in Recife - the site of our empirical research - local political issues prevent community organization or hamper its work with other social actors, especially those located outside the community. A neighborhood that had an intense associative life for about 20 years is now weakened by the action of youth gangs and organized groups that promote drug trafficking. The following was found by Freitas ${ }^{35}$ and confirmed by us on the occasion 
of the Family Health survey: the low density of the Coque network, compared to other neighborhoods, did not allow a satisfactory insertion of the Community Health Workers and consequently the proper execution of the main axes of the program, namely, health promotion and prevention. Actions such as vaccination campaigns, the organization of health promotion groups (elderly, hypertensive, people with diabetes), which are organized in other neighborhoods in partnership with residents' associations, mothers' clubs and NGOs working in the area are hindered.

3. Another interesting example refers to the use of new technologies for public management from the dissemination of the World Wide Web, the Internet. This incredible change, whose endpoints are still unpredicatable, is based on two important vectors: communication, on the one hand, and information, on the other. An extraordinary volume of data is stored and processed with somewhat older computers, allowing for incredible changes in company productivity patterns. Information that is collected, stored, and handled allows administrators to control and perform tasks much more easily. With the Internet, this information may be sent real-time to any part of the planet, which profoundly impacts the global business strategies, since the main vector for the success of a global enterprise is exactly the communicative capacity between the partners. Thus, as Castells shows, what characterizes this technological revolution is that the communication processes spread, producing a "close relationship between the processes of creation and management of symbols and the capacity to produce and distribute goods and services"36.

However, the most astonishing is yet to happen, the complexification of this networked society with ordinary people's access to Information and Communication Technologies. Today, in the second decade of the twentieth century, and therefore about twenty years after the publication of Castells' book, the networked society is not only a central phenomenon in the economic universe, it is found in people's daily lives. With digital exclusion becoming less important with the emergence of more affordable electronic devices (the smartphone is the most emblematic example) and cheaper Internet connections, we can observe that this phenomenon is present in people's daily lives, not only for unilateral communication or search for information, but for the establishment of interactive processes - and this only from the first decade of the twenty-first century, with the emergence of the so-called Internet 2.0 and social media, such as Facebook.

The critical vehicle of current daily sociabilities are sociabilities intermediated by the socalled virtual social networks. Wellman's affirmation in the 1990s that netizens do not navigate alone $^{37}$ is, therefore, increasingly accurate, and he even stated then that virtual communities have the same features as communities with dominant face-to-face interaction. These technologies are also used for the management of public affairs, a phenomenon now receiving several nicknames: e-government, e-governance, e-health (or telehealth), among others. Of the ones that are of immediate interest to us, the idea of government and governance, the issue is whether these management tools, now using Internet-delivered information and communication technologies, would retain the same characteristics. Right away, by consulting the literature on the subject, there is no consensus on what e-government and e-governance means. An essential part of the literature does not distinguish between the two words, incorporating the ingredients of the two phenomena, government and governance. Another group of researchers addresses the original concept by associating the idea of e-governance with that of e-democracy. That is, it only makes sense to think about e-governance when the processes of participation and social control in management are included. Therefore, it seems to us that this idea is more interesting because it allows us to compare with the pre-digital revolution processes of governance ${ }^{38}$.

Seen in this perspective, the phenomenon of e-governance is hardly present in public management practices. Some occurrences are related to social control (accountability), and practically none are associated with the popular participation in the management or decision-making processes. Most of the experiences reported in the literature labeled as e-governance refer to administrative processes with the use of information tools: Rahman ${ }^{39}$ provides us with a compelling account of some Asian countries and their experiences of using information technology in management; just one of the six analyzed, India, attempts to empower citizens for participatory government practices (but not reporting directly to decision-making processes). Other researchers 
mention telecenter services ${ }^{40}$; information and access to public services, thus facilitating bureaucratic procedures ${ }^{41}$; the use of mobile phones as a way of communicating and also accessing public services $^{42}$; the use of data mining in internet-mediated social networks for the knowledge of people's opinions about the government ${ }^{43}$. Concerning health, the fields of action are similar to those observed in other public management areas: facilitating access to services (scheduling visits), information, opening channels of communication between public agents and users, data processing and organization of dossiers, and so forth.

Thus, the idea of digital democracy in the use of participatory public management practices is still very incipient, which allows us to affirm that, strictly speaking, the practice of e-governance is still embryonic. Little has been done besides cases of web-provided social control and accountability, with the existence of ombudsman pages and spaces for reporting and complaints.

Again, in the field of social control, but not formally established as a management tool, internet-mediated social media ${ }^{44}$ hold a vital place in denouncing and publicizing problems of public service provision. What was formerly done by traditional media (television, radio, newspapers), is now multiplied by Facebook, Twitter, YouTube, and other media. Reports of violence, poor service, neglect are now posted, providing a compelling social control mechanism, whose effects are not yet fully understood. In any case, private companies and public institutions have paid attention to this critical flow of news ${ }^{45}$.

\section{Conclusions}

As we have seen, the concept of health governance is constructed to account for recent phenomena of the organizational arrangements of public management, especially from the fact that new actors have come center-stage. It is no longer possible to have a close picture of reality by using traditional organizational analysis models. We have to incorporate other theoretical-methodological tools, and we believe that the analysis of social networks is an essential ally for understanding this complex reality.

It is true that it is a still incipient research agenda, and with essential challenges ahead. We must first consider that the governance model's central requirement is the participation of civil society in the management, which means as much the involvement in the decision processes as in the control over the public actions. The above examples show us that typical-ideal governance constructs are not always found in reality. Political participation implies adequate political culture and citizen awareness, which is not always observed in reality. Well-structured organizational designs do not ensure management success.

Secondly, we also have the fact that organizational cultures are often not favorable to the participatory management model. Strongly hierarchical, non-transparent and population-distanced management practices are often observed in public agencies. In some cases, we can observe resistance of public agents to the new organizational designs, or even the existence of two structures, namely, the formally-established, and the one set to account for the establishment of some participatory levels. The communication between the two sometimes becomes quite complicated, with frequent conflicts.

The delicate balance between an organizational culture refractory to changes and diverse patterns of civil society organization for transparency and management control results in diverse practices. A municipal health council, for example, set up in a city with a strong tradition of clientelistic political culture will probably have among its advisers a significant proportion of people who represent far more the interests of these oligarchies than those of the population they formally represent ${ }^{46-48}$.

Moreover, this fact points to another more delicate and difficult to solve: from the existence of non-functional civic cultures to network governance models. The expression of civic culture coined by Putnam ${ }^{49}$ indicates that societies that do not have among their members the mentality to consider public spaces as sharing and non-appropriation, and consequently not discussing matters of general interest with the community will cause increased inequality and injustice. The variable civic culture is essential for the understanding of all forms of government, from traditional ones that consider exclusively the political representation as an instrument of legitimacy, even those geared to the idea of governance, that incorporates practices of popular management participation into the representative model, a 
participation with the prerequisite of appropriate civic culture. It seems that these questions also apply when one thinks of the idea of e-government, about its conditions of applicability. Even overcoming digital exclusion, it is difficult for a community to achieve something like an electronic agora, a participatory virtual space with a vital community presence, because the conditions of an appropriate civic culture must be fulfilled. 


\section{References}

1. Expatica. A guide to German health insurance. [acessado 2018 Fev 22]. Disponível em: https://www.expatica. com/de/healthcare/German-health-insurance_693463. html

2. Yoshimi OT, Oliveira VE. Reforma(s) e Estruturação do Sistema de Saúde Britânico: lições para o SUS. Saúde Soc 2007; 16(1):7-17.

3. Jansen JN. The quest for therapy. Medical pluralismo in Lower Zaire. Berkely: University of California Press; 1978.

4. Merton RK. Sociologia. Teoria e Estrutura. São Paulo: Editora Mestre Jou; 1968.

5. Offe K. Strukturprobleme des kapitalistischen Staates. Aufsätze zur politischen Soziologie. Frankfurt: Suhrkamp; 1973.

6. Habermas J. Legitimationsprobleme im Spätkapitalismus. Frankfurt am Main: Suhrkamp; 1973.

7. Castells M. The Information age: Economy, society and cultura. Volume I: The rise of network society. Oxford: Blackwell; 1996.

8. Lojkine J. A revolução Informacional. São Paulo: Cortez Editora; 1995.

9. Harvey D. Condição Pós-Moderna. São Paulo: Edições Loyola; 1992.

10. Rémond B, Blanc J. Les collectivités locales. Paris: Presses de la Fondation Nationale des Sciences Politiques; 1989

11. Mabileau A. Les Pouvoirs Locaux à l'Epreuve de la Décentralization. Paris: Ed. Pédone; 1983.

12. Revel-Mouroz J, coordinateur. Pouvoir Local. Régionalismes, Décentralisation. Enjeux Territorial et Territoriatlité en Amérique Latine. Paris: IHEAL; 1989.

13. Fontes BASM, Leal SMR. Gestion locale dans le NordEst du Bresil: la recherche de nouveaux paradigmes. Collection Cahiers Internationaux du PIR Villes 1997; 00:85-108.

14. Fontes BASM. Gestão Urbana e Participação Popular. Organizações \& Sociedade 1997; 1:107-122.

15. Gonçalves A. O conceito de governança. [acessado 2018 Fev 27]. Disponível em: http://www.publicadireito. com.br/conpedi/manaus/arquivos/anais/XIVCongresso/078.pdf

16. Fontes B. Urban Politics and Participative Democracy: A Utopia or a Project of Political Engineering? In: Eichner K, Fontes B, editors. Familie, Soziale Netzwerke und Gesundheitspolitik. Munster, Hamburg, Berlin, Wien: LIT Verlag; 2009. p. 62-76.

17. Capano G, Howlett M, Ramesh M. Bringing Governements Back in: Governance and governing in comparative Policy analysis. Journal of Comparative Policy Analysis: Research and Practice 2015; 17(4):311-321.

18. Kooiman J, Bavinck M, Chuenpadgee R, Mahon R, Pullin R. Interactive Governance and Governability: an introduction. Journal of Transdisciplinary Environmental Studies 2008; 7(1):1-11.

19. Luhman N. Sistemas sociais. Esboço de uma teoria geral. Petrópolis: Vozes; 2016.

20. Holzer B, Fuhse J. Netzwerke aus systemtheoretischer Perspective. In: Stegbauer C, Häussling R, editor. Handbuch Netzwerkforschung. Berlin: VS Verlag; 2010. p. 313-324.

21. Thai MT, Pardalos PM, editors. Handbook of Optimization in complex networks. New York: Springer; 2012.
22. Newman MEJ. Networks: an introduction. New York: Oxford University Press; 2011.

23. Janzen JM. The Quest for Therapy: Medical Pluralism in Lower Zaire (Comparative Studies of Health Systems and Medical Care). Oakland: University of California Press; 1982.

24. Fryatt R, Bennett S, Soucat A. Health sector governance: should we be investing more? BMJ Glob Health 2017; 2(2):e000343.

25. DTJM Peters, Klijn EH, Stronks K, Harting J. Policy coordination and integration, trust, management and performance in public health-related policy networks. International Review of Administrative Sciences 2017; 83(1):200-222.

26. Conselho Nacional de Secretários de Saúde (CONASS). CONASS Debate - Governança Regional das Redes de Atenção à Saúde. Brasília: CONASS; 2016.

27. Newman MEJ. Epidemics on networks. In: Newman MEJ. Networks: an introduction. New York: Oxford University Press; 2011. p. 627-674.

28. Morris M, editor. Network Epidemiology: a handbook for survey design and data collection. Oxford: Oxford University Press; 2004.

29. Fuhse J. Verbindungen und Grenzen. Der netzwerkbegriff in der Systemtheorie. In: Weyer J, editor. Soziale Netzwerke - Konzepte und methoden der Sozialwissenschaftlichen Netzwerkforschung. Müchen: Oldenbourg Wissenschaftsverlag; 2014. p. 291-314.

30. Bruns W. Netzwerkeanalysen in der Forschung zusammenfassung und Diskussion. In: Kulin S, Frank K, Fickermann D, Schwippert K, editors. Soziale Nezwerkanalyse. Theorie, Methoden, Praxis. Munster: Wasmann; 2012. p. 713-184.

31. Martins PH, Fontes B. Construindo o conceito de rede de vigilância em Saúde. In: Martins $\mathrm{PH}$, Fontes B, organizadores. Redes Sociais e Saúde. Novas Possibilidades Teóricas. Recife: Editora da UFPE; 2008. p. 103-120.

32. Fontes B. Interfaces do combate/prevenção de AIDS e Tuberculose em Recife. In: Fontes B, Martins P, organizadores. Redes, práticas associativas e gestão pública. Recife: Editora da UFPE; 2006. p. 75-112.

33. Martins PH, Fontes B. Construindo o conceito de rede de vigilância em Saúde. In: Martins PH, Fontes B, organizadores. Redes Sociais e Saúde. Novas Possibilidades Teóricas. Recife: Editora da UFPE; 2008. p. 103-120.

34. Fontes B, Dornelas M. Redes, Governanza urbana y práticas associativas: el ejemplo del Programa de Salud de la Familia. Estudios Sociologicos de el Colegio de Mexico 2008; XXXVI(76):33-64.

35. Freitas AS. Fundamentos para uma sociologia crítica da Formação Humana: um estudo sobre o papel das redes associativas [tese]. Recife: Universidade Federal de Pernambuco; 2005.

36. Castells M. The rise of network society. In: Manuel Castells, editors. The Information age: Economy, society and cultura. Oxford: Wiley-Blackwell; 1996. Vol. I.

37. Wellman B, Gulia M. Net-surfers don't ride alone: Virtual Community as Community. In: Wellman B, editor. Networks in the Global Village. Life in Contemporary Communities. London: Routledge; 1998. p. 331-366. 
38. Riley CG. The Changing role of the citizen in the e-governance \& e-democracy equation. [acessado 2018 Mar 12]. Disponível em: http://eletronicgov.net

39. Rahman H. Framework of E-governance at the local Government level. In: Reddick CG, editor. Comparative E-Government. New York: Springer Science+Business Media, LLC; 2010. p. 23-48.

40. Rajelksmi K. E-Governance Services Through Telecenters: The Role of Human Intermediary and Issues of Trust. Gopakumar Information Technologies and International Development 2007; 4(1):19-35.

41. Palvia S, Sharma S. 2018. E-Government and E-Governance: Definitions/Domain Framework and Status around the World. [acessado 2018 Fev 2]. Disponível em: file:///L:/E-Government_and_E-Governance_Definitions Domain_Fr.pdf

42. Hellström J. Mobile phones for good governance - challenges and way forward Draft discussion paper. [acessado 2018 Mar 12]. Disponível em: https://www. w3.org/2008/10/MW4D_WS/papers/hellstrom_gov. pdf

43. Rao GK, Dey S. Decision support for e-governance: a texto mining approach. IJMIT 2011; 3(3):73-91.

44. Recuero R. Redes sociais na internet. Porto Alegre: Sulina; 2009.

45. Farranha AC, Silva V. Administração Pública e Redes Sociais (Facebookd e Twitter): Análise de casos selecionados. VII CONSAD. Congresso da Gestão Pública; Brasilia; 2014. [acessado 2018 Mar 14]. Disponível em: http://www.escoladegestao.pr.gov.br/arquivos/File /2014/VII_Consad/016.pdf

46. Cavalcanti ML, Cabral MHP, Antunes LR. Participação em Saúde: uma sistematização de artigos publicados em periódicos brasileiros - 1988/2005. Cien Saude Colet 2012; 17(7):1813-1823.

47. Paiva FS, Stralen CJV, Costa PHA. Participação Social e Saúde no Brasil: revisão sistemática sobre o tema. Cien Saude Colet 2014; 19(2):487-498.

48. Gurgel C, Justen A. Controle Social e políticas públicas: a experiência dos Conselhos Gestores. RAP 2013; 47(2):357-378.

49. Putnam R. Comunidade e Democracia: a experiência da Itália moderna. Rio de Janeiro: Fundação Getúlio Vargas; 1996.

Article submitted 31/01/2018

Approved 06/03/2018

Final version submitted 20/05/18 